\title{
Influence of air mass downward transport on the variability of surface ozone at Xianggelila Regional Atmosphere Background Station, southwest China
}

\author{
J. Ma ${ }^{1, *}$, W. L. Lin ${ }^{1,2}$, X. D. Zheng ${ }^{1}$, X. B. Xu' ${ }^{1}$ Z. Li ${ }^{3}$, and L. L Yang ${ }^{3}$ \\ ${ }^{1}$ Key Laboratory for Atmospheric Chemistry, Chinese Academy of Meteorological Sciences, Beijing 100081, China \\ ${ }^{2}$ Centre for Atmosphere Watch and Services, Meteorological Observation Centre, China Meteorological Administration, \\ Beijing 100081, China \\ ${ }^{3}$ Yunnan Diqing Meteorological Bureau, Diqing 674400, China \\ *now at: Atmospheric Research Center, Fok Ying Tung Graduate School, Hong Kong University of Science and Technology, \\ Hong Kong
}

Correspondence to: W. L. Lin (linwl@ cams.cma.gov.cn)

Received: 13 November 2013 - Published in Atmos. Chem. Phys. Discuss.: 21 January 2014

Revised: 4 April 2014 - Accepted: 16 April 2014 - Published: 2 June 2014

\begin{abstract}
In situ measurements of ozone $\left(\mathrm{O}_{3}\right)$, carbon monoxide $(\mathrm{CO})$ and meteorological parameters were made from December 2007 to November 2009 at the Xianggelila Regional Atmosphere Background Station $\left(28.006^{\circ} \mathrm{N}\right.$, $99.726^{\circ} \mathrm{E} ; 3580 \mathrm{~m}$ a.s.1.), southwest China. It was found that both $\mathrm{O}_{3}$ and $\mathrm{CO}$ peaked in spring while the minima of $\mathrm{O}_{3}$ and $\mathrm{CO}$ occurred in summer and winter, respectively. A normalized indicator (marked as " $Y$ ") on the basis of the monthly normalized $\mathrm{O}_{3}, \mathrm{CO}$ and water vapor, is proposed to evaluate the occurrence of $\mathrm{O}_{3}$ downward transport from the upper, $\mathrm{O}_{3}$-rich atmosphere. This composite indicator has the advantage of being less influenced by the seasonal or occasional variations of individual factors. It is shown that the most frequent and effective transport occurred in winter (accounting for $39 \%$ of the cases on the basis of a threshold of the $Y$ value larger than 4) and they can make a significant contribution to surface $\mathrm{O}_{3}$ at Xianggelila. A $9.6 \mathrm{ppb}$ increase (21.0\%) of surface ozone is estimated based on the impact of deep downward transport events in winter. A case of strong $\mathrm{O}_{3}$ downward transport event under the synoptic condition of a deep westerly trough is studied by the combination of the $Y$ indicator, potential vorticity, total column ozone and trajectory analysis. Asian monsoon plays an important role in suppressing $\mathrm{O}_{3}$ accumulation in summer and fall. The seasonal variation of $\mathrm{O}_{3}$ downward transport, as suggested by the $Y$ indicator at Xianggelila, is consistent with the seasonality of
\end{abstract}

stratosphere-to-troposphere transport and the subtropical jet stream over the Tibetan Plateau.

\section{Introduction}

Tropospheric $\mathrm{O}_{3}$ has been significantly increasing for more than a century due to anthropogenic activities (Hough and Derwent, 1990; Staehelin et al., 2001; Vingarzan, 2004), deteriorating the air quality and potentially harming human beings and the ecosystem (Krupa and Manning, 1988). In the troposphere, $\mathrm{O}_{3}$ is known to be produced by gas-phase oxidation of hydrocarbons and $\mathrm{CO}$ through the catalysis of hydrogen oxide radicals and nitrogen oxides in the presence of sunlight (Chameides and Walker, 1973; Crutzen, 1974; Crutzen et al., 1999; Jacob, 2000). In addition to photochemical production, tropospheric $\mathrm{O}_{3}$ also comes from the stratosphere (Junge, 1962; Danielsen, 1968). Although the chemical production is regarded as the main source of tropospheric $\mathrm{O}_{3}$ (Fishman et al., 1979; Gidel and Shapiro, 1980), the influence of $\mathrm{O}_{3}$ transported from the stratosphere is considerable at some background sites where the regional and local emissions of $\mathrm{O}_{3}$ precursors are extremely limited (Ordóñez et al., 2007; Trickl et al., 2010; Logan et al., 2012; Oltmans et al., 2013; Parrish et al., 2012). Due to the stratosphereto-troposphere exchange (STE) and the distance from the earth's surface, where sources of trace species are located, 
air in the upper troposphere often shows a unique chemical signature. Aircraft measurements show that the climatological levels of $\mathrm{O}_{3}, \mathrm{CO}$ and $\mathrm{H}_{2} \mathrm{O}$ in the upper troposphere and lower stratosphere (UTLS) over the subtropics of the Northern Hemisphere are, respectively, in the ranges of 80-160 ppb, 50-85 ppb and 6-40 ppm, depending on season (Tilmes et al., 2010). Therefore, transport events of air masses associated with stratospheric intrusions were usually characterized by high $\mathrm{O}_{3}$ but low $\mathrm{CO}$ and water vapor concentrations (Marenco et al., 1998; Bonasoni et al., 2000; Stohl et al., 2000; Cooper et al., 2002; Wang et al., 2006; Langford et al., 2009; Neuman et al., 2012). Such transport events are often associated with tropopause-folding synoptic systems in the middle latitudes, such as cold fronts in the lower troposphere (Stohl and Trickl, 1999), corresponding with troughs/cutoff lows in the middle and upper troposphere (Davies and Schuepbach, 1994). In mid-latitudes, the subtropical jet (STJ) stream can have a significant effect on the vertical ozone distribution, and the STJ varies from a wintertime maximum to a summertime minimum (Bukin et al., 2011; Koch et al., 2006). Sprenger et al. (2003) found that the downward transfer along the STJ could be even more important than the stratosphere-to-troposphere transport (STT) in the mid-latitudes and there are indications of long-range transport of high-ozone air masses that emerged from shallow STT along the STJ (Langford et al., 1998; Langford, 1999; Koch et al., 2006; Trickl et al., 2011). Near the STJ, the occurrence frequency of double tropopauses shows a strong seasonal variation over northern hemispheric mid-latitudes, with a 50-70\% occurrence in profiles during winter and a small fraction $(\sim 10 \%)$ over most of the hemisphere during summer (Randel et al., 2007); the multiple tropopause occurrence over the Tibetan Plateau can be as high as $80 \%$ during certain winters (Chen et al., 2011). In addition, the Asian and North American monsoons may have distinct effects on the upper troposphere and lower stratosphere (Gettelman et al., 2004).

The Tibetan Plateau and the surrounding mountains cover about $3000000 \mathrm{~km}^{2}$, with an average elevation in excess of $4000 \mathrm{~m}$ a.s.l.. The kinetics and thermodynamics of this unique topography have a great impact on air circulation and climate change on local, regional or even global scales. It is important to understand the influence of transport events from the upper troposphere and the lower stratosphere, which may represent one of the most important natural inputs of tropospheric $\mathrm{O}_{3}$ and impact the atmospheric radiative forcing in the Tibetan Plateau. Moore and Semple (2005) reported the existence of the so-called Tibetan "Taylor Cap" and a halo of stratospheric $\mathrm{O}_{3}$ over the Himalaya, which causes elevated levels of the upper tropospheric $\mathrm{O}_{3}$ in the mountain regions. This result strongly suggests that the topography of the Tibetan Plateau can exert an influence on the lower stratosphere and upper troposphere. Škerlak et al. (2014) compiled a global $33 \mathrm{yr}$ climatology of STE from 1979 to 2011 and concluded that the Tibetan Plateau is one of the global hot spots for deep STE, where the very high orography combined with a high mixing layer enables quasi-horizontal transport into the Planetary boundary layer (PBL) (Chen et al., 2013). So far, surface $\mathrm{O}_{3}$ measurements in the Tibetan Plateau have been reported mainly for the Waliguan global WMO/GAW (the World Meteorological Organization (WMO)/the Global Atmosphere station Watch $(\mathrm{GAW}))\left(36.28^{\circ} \mathrm{N}, 100.90^{\circ} \mathrm{E} ; 3816 \mathrm{~m}\right.$ a.s.l. $)$ in the northeastern plateau since 1994 (Tang et al., 1995; Klausen et al., 2003; Wang et al., 2006; Xu et al., 2011) and, on the southern rim, for the Nepal Climate Observatory-Pyramid (NCO$\mathrm{P} ; 27.95^{\circ} \mathrm{N}, 86.80^{\circ} \mathrm{E} ; 5079 \mathrm{~m}$ a.s.l.) in the Himalaya range (Cristofanelli et al., 2010). At Waliguan, high- $\mathrm{O}_{3}$ events were mostly observed when transport events of the upper troposphere-lower stratosphere air occurred in spring (Ding and Wang, 2006; Zheng et al., 2011), and the summertime $\mathrm{O}_{3}$ peak was deemed to be greatly influenced by a vertical mixing process including the stratosphere-troposphere exchange (Ma et al., 2002, 2005; Zheng et al., 2005; Liang et al., 2008) as well as the transport of anthropogenic pollution from central and eastern China (Xue et al., 2011). Based on the measurements at NCO-P, Cristofanelli et al. (2010) assessed the influence of stratospheric intrusions (SI) on surface $\mathrm{O}_{3}$ and concluded that $14.1 \%$ of analyzed days were found to be affected by SI during a 2 yr investigation.

In this paper, we present $2 \mathrm{yr}$ (from December 2007 to November 2009) measurements of surface $\mathrm{O}_{3}$ and $\mathrm{CO}$ at the Xianggelila station, which is located at the southeastern rim of the Tibetan Plateau in southwest China. Firstly, we give a general introduction to the study, including the description of observation sites, measurements of $\mathrm{O}_{3}$ and $\mathrm{CO}$, and the methods of analysis. Then, we summarize the seasonal variations of $\mathrm{O}_{3}$ and $\mathrm{CO}$, and show the main patterns of airflow which may influence the Xianggelila site. We study the impact of downward transport on surface $\mathrm{O}_{3}$ using a normalized indicator of downward transport, which is less influenced by seasonality of trace species. In addition, we show analysis results of backward trajectories combined with the surface measurement data and demonstrate a case of $\mathrm{O}_{3}$ transport event caused by a deep westerly trough. Finally, the influence of air mass transport from the upper $\mathrm{O}_{3}$-rich atmosphere on the surface $\mathrm{O}_{3}$ is assessed using chemical tracers.

\section{Measurements and methodologies}

\subsection{Overview of the Xianggelila station}

The Xianggelila Regional Atmosphere Background Station $\left(28.006^{\circ} \mathrm{N}, 99.726^{\circ} \mathrm{E} ; 3580 \mathrm{~m}\right.$ a.s.l.) is located in Yunnan province, southwest China (Fig. 1), and is one of the background stations operated by the China Meteorological Administration (CMA). The station is at the southeastern rim of the Tibetan Plateau and about $450 \mathrm{~km}$ northwest of Kunming City (population about 7.263 million in 2011), the capital of 


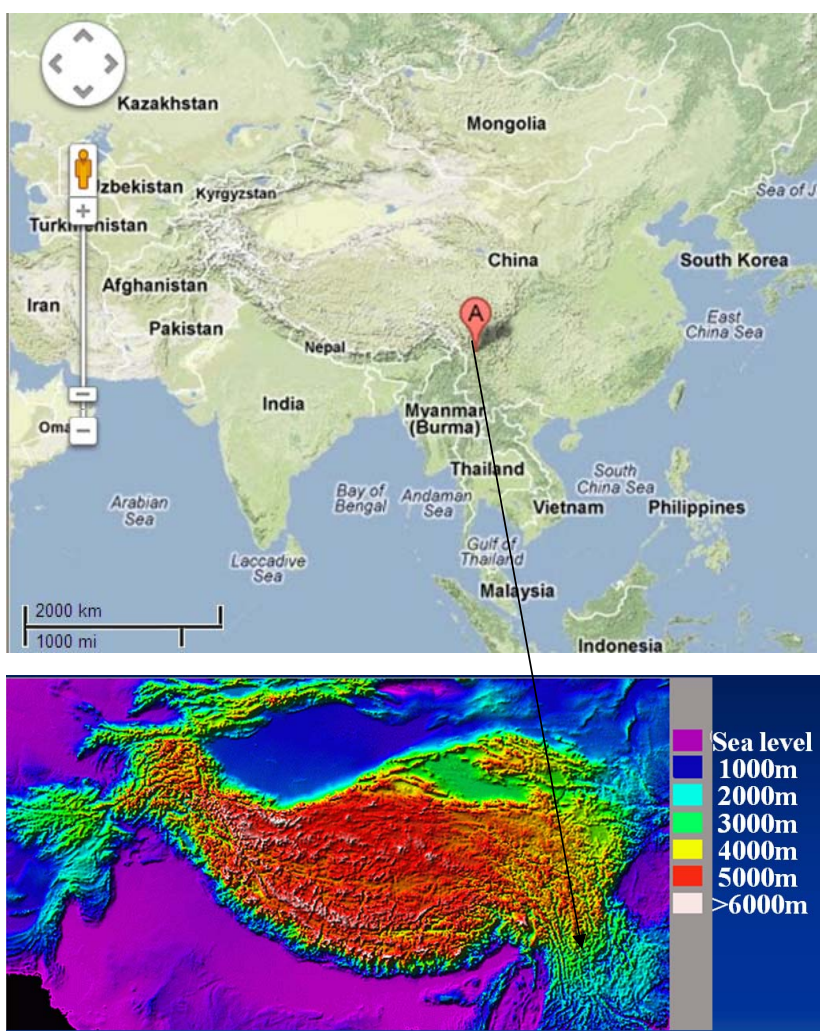

Figure 1. The geographical location of the Xianggelila Regional Atmosphere Background Station (the upper image is taken from Google Maps and the bottom image is taken from NASA Earth).

Yunnan province. It is considered to be weakly affected by local anthropogenic activities because there is nearly no significant anthropogenic source of $\mathrm{O}_{3}$ precursors surrounding the station and the nearest township, Xianggelila, is about $30 \mathrm{~km}$ away from the station. Hence, it is regarded as an ideal site for monitoring the background levels of trace gases in the atmosphere over southwest China. The climatology of Xianggelila is mainly controlled by monsoon activities. The Asian summer monsoon can bring abundant precipitation there.

\subsection{Measurements of $\mathrm{O}_{3}$ and $\mathrm{CO}$}

A set of commercial instruments from Ecotech, Australia, was used to measure $\mathrm{O}_{3}(9810 \mathrm{~B})$ and $\mathrm{CO}(9830 \mathrm{~T})$ at the $\mathrm{Xi}$ anggelila station. The linearity errors for $9810 \mathrm{~B}$ and $9830 \mathrm{~T}$ are $\pm 0.5 \%$ and $\pm 1 \%$, respectively. The lower detection limits for $9810 \mathrm{~B}$ and $9830 \mathrm{~T}$ are $0.4 \mathrm{ppb}$ and $25 \mathrm{ppb}$, respectively. The air inlet is fixed at the height of $1.8 \mathrm{~m}$ above the roof of the building and about $8 \mathrm{~m}$ above the ground. The common inlet and all other tubing are made of Teflon. Weekly zero/span checks were done using a dynamic gas calibrator (Gascal 1100) in combination with a zero-air supply (8301LC) and a set of standard reference gas mixtures (National Institute of Metrology, Beijing, China). Additional
CO-free air was also produced using SOFNOCAT (514) oxidation catalysts (www.molecularproducts.com) and supplied to the $\mathrm{CO}$ analyzer every $2 \mathrm{~h}$ for additional auto-zero (background) cycles. Multipoint calibrations of the $\mathrm{CO}$ analyzers were made every month. The national $\mathrm{CO}$ standard gas was compared against the NIST-traceable (National Institute of Standards and Technology) standard from Scott Specialty Gases, USA. Multipoint calibrations of the $\mathrm{O}_{3}$ analyzer were made every month using an $\mathrm{O}_{3}$ calibrator (TE 49i PS), which is traceable to the Standard Reference Photometer (SRP) maintained by the WMO World Calibration Centre in Switzerland (EMPA). Measurement signals were recorded as $1 \mathrm{~min}$ averages. After the correction of data on the basis of the results of the multipoint calibrations and zero/span checks, hourly average concentrations were calculated and are used for further analysis. Meteorological data, including wind, temperature, relative humidity, etc., were also obtained from the site, with a resolution of $1 \mathrm{~h}$.

\subsection{Backward-trajectory calculation and weather simulation}

The HYSPLIT (Hybrid Single-Particle Lagrangian Integrated Trajectory, version 4.8) model (http://ready.arl.noaa. gov/HYSPLIT.php) was used to calculate the backward trajectories at Xianggelila from 2007 to 2009. The HYSPLIT model is a complete system for computing simple air parcel trajectories to complex dispersion and deposition simulations (Draxler and Rolph, 2003; Rolph, 2010). The National Centers for Environmental Prediction (NCEP, $1^{\circ} \times 1^{\circ}$ ) reanalysis meteorological data were inputted for model calculation. The vertical motion method in the calculations is the default model selection; it uses the meteorological model's vertical velocity fields and is terrain following. The height of the endpoint is set at $500 \mathrm{~m}$ above ground level. The three-day backward trajectories were calculated four times (00:00, 06:00, 12:00, 18:00 UTC) per day. After calculation, the trajectories were clustered into several types using the HYSPLIT software. In addition, HYSPLIT was also used to calculate seven-day backward trajectories in a case study described in Sect. 3.3.

The Weather Research and Forecasting (WRF) Model Version 3.4.1 (Skamarock et al., 2005) is used to simulate the weather situations in Sect. 3.3 for a case study. Only one domain was initialized by NCEP (National Centers for Environmental Prediction), FNL (final) Operational Global Analysis data on $1.0^{\circ} \times 1.0^{\circ}$ grids prepared operationally every six hours, and the space resolution of WRF is set to $36 \mathrm{~km}$. The run time of WRF was set as two days and used default physical schemes.

\subsection{Normalized indicator of $\mathrm{O}_{3}$ downward transport}

It is known that some species, like $\mathrm{O}_{3}$ and Be-7, are relatively high, while others, like $\mathrm{CO}$ and water vapor, are relatively 
low in the upper troposphere and stratosphere. Therefore, if air masses originate from a higher elevation, for example, from the free troposphere or higher, they often contain more abundant $\mathrm{O}_{3}$, but less $\mathrm{CO}$ and water vapor. Cristofanelli et al. (2009) proposed a stratospheric intrusion index using baseline measurements of $\mathrm{O}_{3}, \mathrm{Be}-7$ and relative humidity. Such an index can be used to quantify the impact of stratospheric intrusion on ground measurements. However, long-term measurements of $\mathrm{Be}-7$ are available only from few sites. Here, we try to infer whether the surface $\mathrm{O}_{3}$ is affected by transport events from upper $\mathrm{O}_{3}$-rich atmosphere or not according to the surface-observed $\mathrm{O}_{3}, \mathrm{CO}$ and water data. These data are available from our site and many other sites. However, the levels of $\mathrm{O}_{3}, \mathrm{CO}$ and water vapor in the UTLS region show seasonal variations (Tilmes et al., 2010) and so do their surface levels. This may make the results from different seasons less comparable. To minimize the effects of seasonal variations, we propose a normalized indicator of downward transport. For a certain period, such as a month, a quantity $\mathrm{Y}$, which combines the measured data of the chemical tracers of $\mathrm{O}_{3}, \mathrm{CO}$ and water vapor, is determined as Eq. (1).

$Y=\frac{\left[\mathrm{O}_{3}\right]}{[\mathrm{r}][\mathrm{CO}]}$,

where, $\left[\mathrm{O}_{3}\right]$, $[\mathrm{CO}]$ and $[\mathrm{r}]$ denote the monthly normalized $\mathrm{O}_{3}$, $\mathrm{CO}$ and water vapor mixing ratios, respectively. For example, $\left[\mathrm{O}_{3}\right]$ is an hourly averaged $\mathrm{O}_{3}$ concentration divided by the monthly averaged $\mathrm{O}_{3}$ concentration. As $Y$ is a composite indicator, it should be less subject to occasional disturbance in any of the individual factors. The water vapor mixing ratio is calculated using the local meteorological observational data and normalized in the same way. Here, the $Y$ indicator is used to indicate the synthesized fluctuation of $\mathrm{O}_{3}, \mathrm{CO}$ and water vapor, which acts as a surface chemical tracer to understand the exchange of surface air with the free or upper atmosphere. The conserved physical process of downward transport is assumed by the $Y$ indicator, and this is inevitably influenced by the photochemical processes of $\mathrm{O}_{3}$ and $\mathrm{CO}$. In situations when the physical processes are much more dominant than the local photochemical production in sources of surface $\mathrm{O}_{3}$, the $Y$ indicator is expected to act as a good tracer.

\section{Results and discussion}

\subsection{Seasonal and diurnal variations of $\mathrm{O}_{3}$ and $\mathrm{CO}$}

The monthly averaged $\mathrm{O}_{3}$ and $\mathrm{CO}$ are shown in Table 1. Both $\mathrm{O}_{3}$ and $\mathrm{CO}$ reached maxima in spring $\left(\mathrm{O}_{3}: 55.2 \pm 9.3 \mathrm{ppb}\right.$; CO: $183 \pm 57 \mathrm{ppb}$ ), and the highest monthly averaged $\mathrm{O}_{3}$ concentrations of $58.3 \mathrm{ppb}$ appeared in April. The spring maximum of $\mathrm{O}_{3}$ at Xianggelila is consistent with the observations at background sites elsewhere in the Northern Hemisphere (Monks, 2000). In winter, the concentration of CO is low with an average level of $137 \mathrm{ppb}$, but the concentration
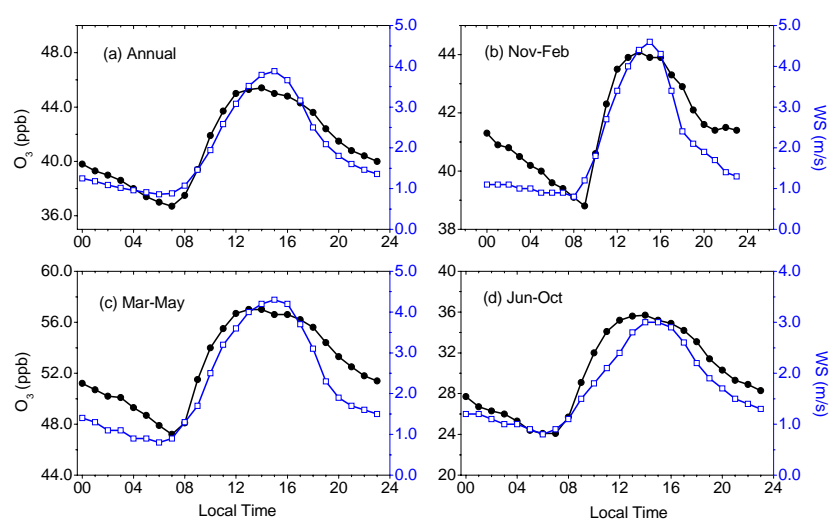

Figure 2. The average diurnal variations of $\mathrm{O}_{3}$ and wind speed (WS) at the Xianggelila station for different periods.

of $\mathrm{O}_{3}$ is still relatively high with an average level of $45.8 \mathrm{ppb}$. By contrast, the $\mathrm{O}_{3}$ level is low in summer and fall $(29.5 \mathrm{ppb}$ and $33.0 \mathrm{ppb}$, respectively), but $\mathrm{CO}$ remains at a relatively high level (152 ppb and $134 \mathrm{ppb}$ for summer and fall, respectively).

Table 1 also shows the maxima and minima of the average diurnal variation of $\mathrm{O}_{3}$ in different months. The average diurnal variation of $\mathrm{O}_{3}$ at Xianggelila reaches a maximum in the early afternoon (12:00-14:00, local time) and a minimum in the early morning. This diurnal ozone pattern seems very similar to the typical diurnal $\mathrm{O}_{3}$ pattern in urban or polluted area, where photochemically produced $\mathrm{O}_{3}$ can accumulate starting in the late morning. However, at Xianggelila, the peak $\mathrm{O}_{3}$ at daytime is strongly associated with the wind speed, as shown in Fig. 2. In the early morning, the $\mathrm{O}_{3}$ mixing ratios increase sharply with the increasing wind speed. During the high-wind-speed period (12:00-16:00, local time), $\mathrm{O}_{3}$ maintains high levels, and then, until the beginning of the night, $\mathrm{O}_{3}$ decreases with the decrease of wind speed when the turbulent downward mixing from a reservoir diminishes and deposition becomes more important. Strong wind is not conducive to an increase in local photochemical production of $\mathrm{O}_{3}$ and it also can force $\mathrm{O}_{3}$ losses by processes like deposition. Therefore, the transport and deposition will be the key factors influencing the diurnal variations of surface $\mathrm{O}_{3}$ at Xianggelila, a remote and clean site, rather than local photochemical processes.

The amplitude of the diurnal variation of $\mathrm{O}_{3}$ varies as a function of the season. The maximal amplitude was found in spring and the minimal in winter. In spring, the average daytime level of $\mathrm{CO}$ is the highest among the four seasons. A positive correlation between $\mathrm{O}_{3}$ and $\mathrm{CO}$ (slope: 0.154; $P<0.0001)$ during the daytime (10:00-18:00) in spring can be derived using the reduced-major-axis regression technique. Such positive $\mathrm{O}_{3}-\mathrm{CO}$ correlation suggests photochemical production of $\mathrm{O}_{3}$ from anthropogenic sources. This indicates the importance of the photochemical origin of the spring peak. In the monsoon season, the lowest diurnal 
Table 1. Monthly mean $\mathrm{O}_{3}$ and $\mathrm{CO}$, and the average diurnal $\mathrm{O}_{3}$ maxima, minima and amplitudes.

\begin{tabular}{l|cccc|c}
\hline Month & \multicolumn{4}{|c|}{$\mathrm{O}_{3}[\mathrm{ppbv}]$} & $\mathrm{CO}[\mathrm{ppbv}]$ \\
\hline & Mean \pm SD & $\begin{array}{c}\text { Diurnal max } \\
\text { (local time) }\end{array}$ & $\begin{array}{c}\text { Diurnal min } \\
\text { (local time) }\end{array}$ & $\begin{array}{c}\text { Diurnal } \\
\text { amplitude }\end{array}$ & Mean \pm SD \\
\hline Jan & $45.4 \pm 5.6$ & $49.2(14: 00)$ & $41.4(08: 00)$ & 7.9 & $139 \pm 56$ \\
Feb & $50.6 \pm 5.8$ & $54.3(12: 00)$ & $47.2(08: 00)$ & 7.1 & $153 \pm 46$ \\
Mar & $57.1 \pm 6.9$ & $61.4(12: 00)$ & $50.5(08: 00)$ & 10.8 & $185 \pm 57$ \\
Apr & $58.3 \pm 8.8$ & $63.7(13: 00)$ & $50.1(07: 00)$ & 13.6 & $182 \pm 59$ \\
May & $50.2 \pm 9.8$ & $58.4(13: 00)$ & $39.9(07: 00)$ & 18.5 & $181 \pm 54$ \\
Jun & $37.4 \pm 11.6$ & $46.6(13: 00)$ & $27.9(06: 00)$ & 18.7 & $146 \pm 40$ \\
Jul & $26.8 \pm 12.5$ & $34.8(13: 00)$ & $18.5(07: 00)$ & 16.3 & $153 \pm 47$ \\
Aug & $24.2 \pm 8.8$ & $31.8(13: 00)$ & $17.3(06: 00)$ & 14.5 & $156 \pm 42$ \\
Sep & $29.6 \pm 9.2$ & $37.7(13: 00)$ & $20.3(06: 00)$ & 17.4 & $159 \pm 41$ \\
Oct & $31.4 \pm 10.1$ & $37.5(14: 00)$ & $24.1(08: 00)$ & 13.4 & $124 \pm 36$ \\
Nov & $38.1 \pm 7.8$ & $42.8(14: 00)$ & $33.1(09: 00)$ & 9.7 & $118 \pm 44$ \\
Dec & $39.7 \pm 5.0$ & $44.7(14: 00)$ & $36.1(10: 00)$ & 8.6 & $119 \pm 53$ \\
\hline
\end{tabular}

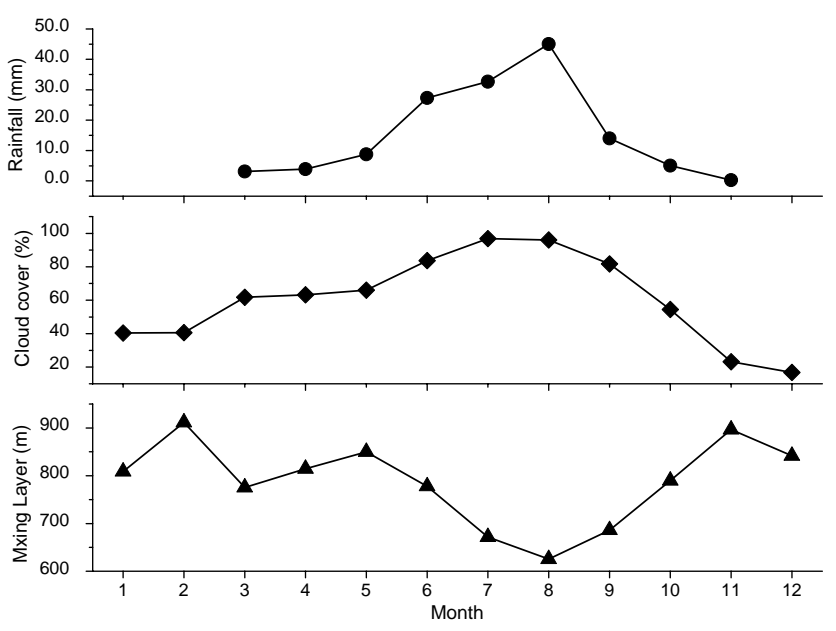

Figure 3. Monthly variations of rainfall, cloud cover and boundary mixing layer height at Xianggelila station.

amplitude was found in August (14.5 ppb, smaller than that in June, July and September). In August, the precipitation and cloud coverage reached the annual maximum and the mixing layer height reached the minimum (Fig. 3). The boundary mixing layer height is calculated using the surface meteorological data according to the method proposed by Cheng et al. (2001). The cloud may decrease the solar radiation and weaken ability of free atmosphere and surface to mix. The precipitation can remove more $\mathrm{O}_{3}$ and its precursors from the troposphere. These factors together contribute significantly to the low level of the average surface $\mathrm{O}_{3}$ and the smaller diurnal amplitude of $\mathrm{O}_{3}$ in monsoon season, especially in August.

\subsection{Trajectory and surface measurements}

Three-day air mass backward trajectories during the measurement period were calculated for every $6 \mathrm{~h}$ and then grouped into seven clusters according to their spatial similarity. The mean trajectory for each cluster, their fractions (the number of trajectories in each cluster to the total number of the trajectories) and their patterns are shown in Fig. 4. The average temperature, water vapor, $\mathrm{O}_{3}$ and $\mathrm{CO}$ corresponding to each type of cluster are listed in Table 2 . The dominant clusters are type $6(55.1 \%)$, type $5(28.1 \%)$ and type 7 $(7.3 \%)$, with low-level trajectory heights and relatively high CO level over $135 \mathrm{ppb}$. Types 5-7 can be recognized as relatively polluted clusters. $\mathrm{O}_{3}$ in types 6 and 7 is lowest because these types of trajectories occur mainly in summer and fall, when Xianggelila is influenced by monsoon and abundant precipitation, which inhibit the photochemical accumulation of $\mathrm{O}_{3} . \mathrm{O}_{3}$ in type 5 is $44.8 \mathrm{ppb}$, a relatively high level, and this type of trajectories mostly occurs in spring and winter with less rain. Trajectories of types 1-4 have high transport height and low $\mathrm{CO}$, so they can be recognized as cleaner types in terms of $\mathrm{CO}$. However, $\mathrm{O}_{3}$ in types $1-4$ is relatively high, indicating that these types of trajectories possibly carry $\mathrm{O}_{3}$-rich air mass from the free troposphere to the surface. Types 1-4 mainly occur in winter, spring and fall, and very rarely in summer.

Figure 5 shows the kernel density of the trajectory pressure level (the minimal one during $72 \mathrm{~h}$ backward trajectories), trajectory height (the maximal one during 72-h backward trajectories) and hourly $Y$ indicator. In summer, trajectories are most likely to travel very low with high pressure levels, and the smallest $Y$ indicators are observed. The spring kernel density of the trajectory resembles that in fall, but the $Y$ indicator in spring has a lower probability when the $Y$ value is between 3 and 7 than in fall. This reflects that the $Y$ indicator is able to indicate the different behavior of $\mathrm{O}_{3}$ in different 
Table 2. Average air temperature $\left({ }^{\circ} \mathrm{C}\right)$, wind speed $\left(\mathrm{m} \mathrm{s}^{-1}\right)$, specific humidity $\left(\mathrm{g} \mathrm{kg}^{-1}\right), \mathrm{O}_{3}$ and $\mathrm{CO}$ volume mixing ratios (ppb) associated with different types of trajectories and seasonal fractioning of trajectories.

\begin{tabular}{lrrrrrrrrr}
\hline Type & $T$ & $\begin{array}{r}\text { Wind } \\
\text { speed }\end{array}$ & humidity & $\mathrm{O}_{3}$ & $\begin{array}{r}\mathrm{CO} \\
\text { Spring } \\
(\%)\end{array}$ & $\begin{array}{r}\text { Summer } \\
(\%)\end{array}$ & $\begin{array}{r}\text { Fall } \\
(\%)\end{array}$ & $\begin{array}{r}\text { Winter } \\
(\%)\end{array}$ \\
\hline 1 & -1.9 & 2.8 & 1.5 & 53.5 & 99 & 50.0 & 0.0 & 0.0 & 50.0 \\
2 & 5.0 & 1.8 & 5.0 & 43.8 & 126 & 38.6 & 18.6 & 17.1 & 25.7 \\
3 & 1.6 & 2.1 & 2.1 & 40.5 & 93 & 4.0 & 0.0 & 28.0 & 68.0 \\
4 & 0.9 & 1.9 & 2.4 & 36.0 & 98 & 10.2 & 0.7 & 21.1 & 68.0 \\
5 & 3.2 & 2.3 & 4.2 & 44.8 & 139 & 46.8 & 2.2 & 17.4 & 33.6 \\
6 & 7.1 & 1.9 & 7.9 & 32.6 & 135 & 17.1 & 37.4 & 28.3 & 17.3 \\
7 & 9.5 & 1.6 & 9.7 & 27.6 & 150 & 14.6 & 49.5 & 35.8 & 0.0 \\
\hline
\end{tabular}

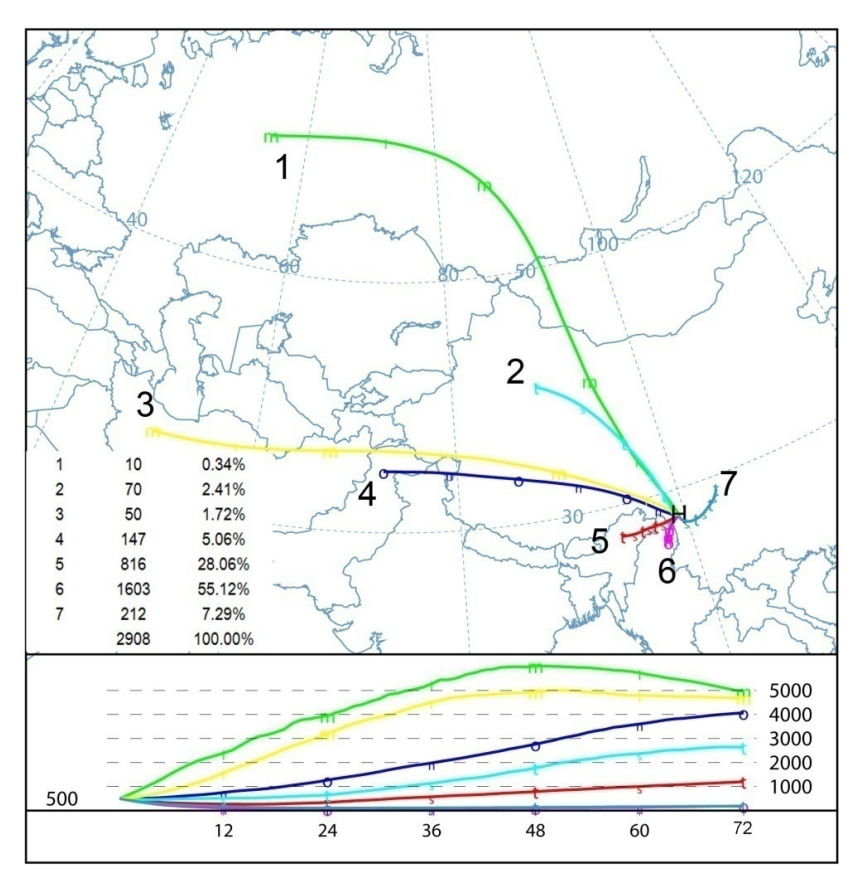

Figure 4. Mean backward trajectories ending at Xianggelila. The endpoint height is $500 \mathrm{~m}$ a.g.l. The numbers of trajectories in each cluster and their percent ratios compared to the total trajectories are shown. The unit of trajectory height is $\mathrm{m}$ a.g.l.

seasons. It is intriguing that the kernel density of trajectories in winter has a peak between 200 and $500 \mathrm{hPa}$, and, accordingly, the density of the $Y$ indicator is much higher in winter than in other seasons. This is consistent with the seasonality of stratosphere-to-troposphere transport (Sprenger and Wernli, 2003; Sprenger et al., 2003) and the subtropical jet events (Koch et al., 2006) in the Northern Hemisphere. The results from Sprenger et al. (2003) demonstrate that, during winter, the frequency of shallow tropopause folds is highest above the Tibetan Plateau (see Fig. 3 in their paper). Škerlak et al. (2014) concluded that, as one of the clear hot spots of deep STT fluxes into the continental PBL, there are also intense deep STT fluxes over the Tibetan Plateau during the whole year, with a peak in winter. On the basis of intensive radiosonde observations, Chen et al. (2011) concluded that the multiple tropopause, which is associated with tropopause folds near the subtropical westerly jet, occurs in winter with a high frequency over the Tibetan Plateau, and, as a result, the intrusion of air masses from the stratosphere may contribute to a higher upper tropospheric $\mathrm{O}_{3}$ concentration in winter than in summer above the plateau. The high probability of a low trajectory pressure level and the high $Y$ value in winter implies the high probability of the occurrence of ozone downward transport in winter. In spring and fall, small peaks of the kernel density of the trajectory pressure level and height are also obvious around the low pressure level at about $200 \mathrm{hPa}$ to $400 \mathrm{hPa}$ (1000 to $3000 \mathrm{~m}$ a.g.l.), but their probability is much lower than that in winter. What is intriguing is that the probability of low trajectory pressure levels and height peaks is a little higher in spring than in fall, but the occurrence of a large $Y$ indicator is higher in fall than in spring. This reverse behavior of the trajectory and the $Y$ indicator in spring and fall might imply that air mass transport from high altitudes does not necessarily enhance the $\mathrm{O}_{3}$ level and its variation, especially in spring, when photochemical production might be a significant source of $\mathrm{O}_{3}$. It is interesting to see that there is a winter maximum around the UTLS region in the pressure panel of Fig. 5, but no maximum in the height panel. The actual reason for this is clear. The pressure levels are more comparable than the heights because the latter are terrain following and given in metres above ground level. It should be noted that there exists a tiny peak in the kernel probability density at pressures around $430 \mathrm{hPa}$, a height of around $4800 \mathrm{~m}$ and the $Y$ indicator around 8 in summer. This is due to a strong ozone transport event and will be discussed in Sect. 3.3.

Figure 6 shows the trajectory pressure level (or height a.g.l.) and the $Y$ indicator in each month with their correlation coefficients and significance levels ( $P$ values). The seasonal variation of the $Y$ indicator shows a maximum in winter (2.5 to 3.0), a slight downward trend from spring to fall (1.5 to 2.0) and reaches the lowest level $(<1.5)$ in August. The trend of the trajectory height is similar to that of $Y$ indicator, while the trajectory pressure level shows an inverse trend. 

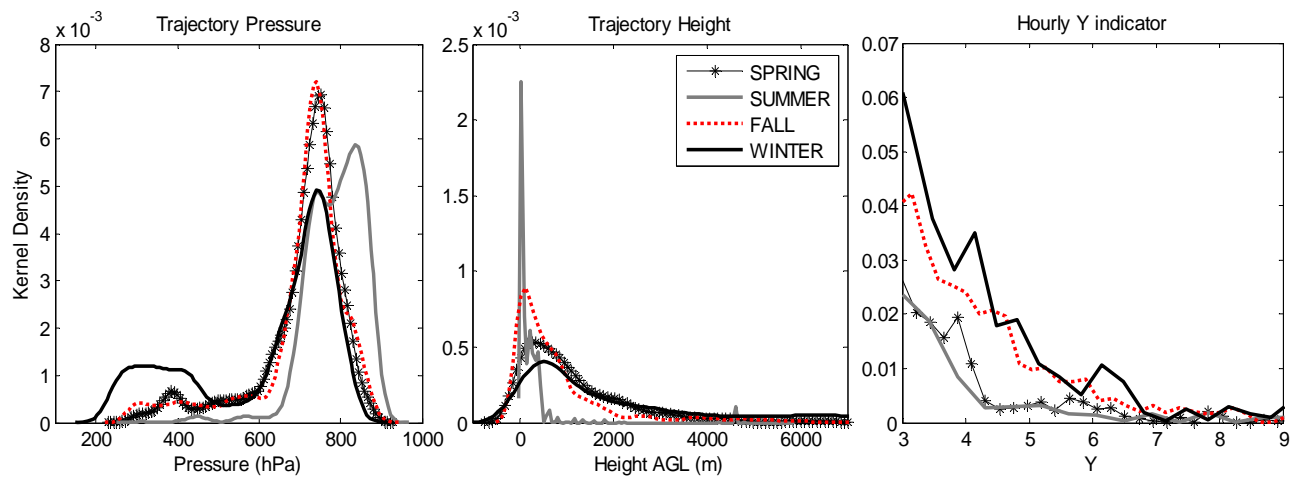

Figure 5. Kernel probability density of trajectory pressure level, trajectory height above ground level and hourly $Y$ indicator in each season.
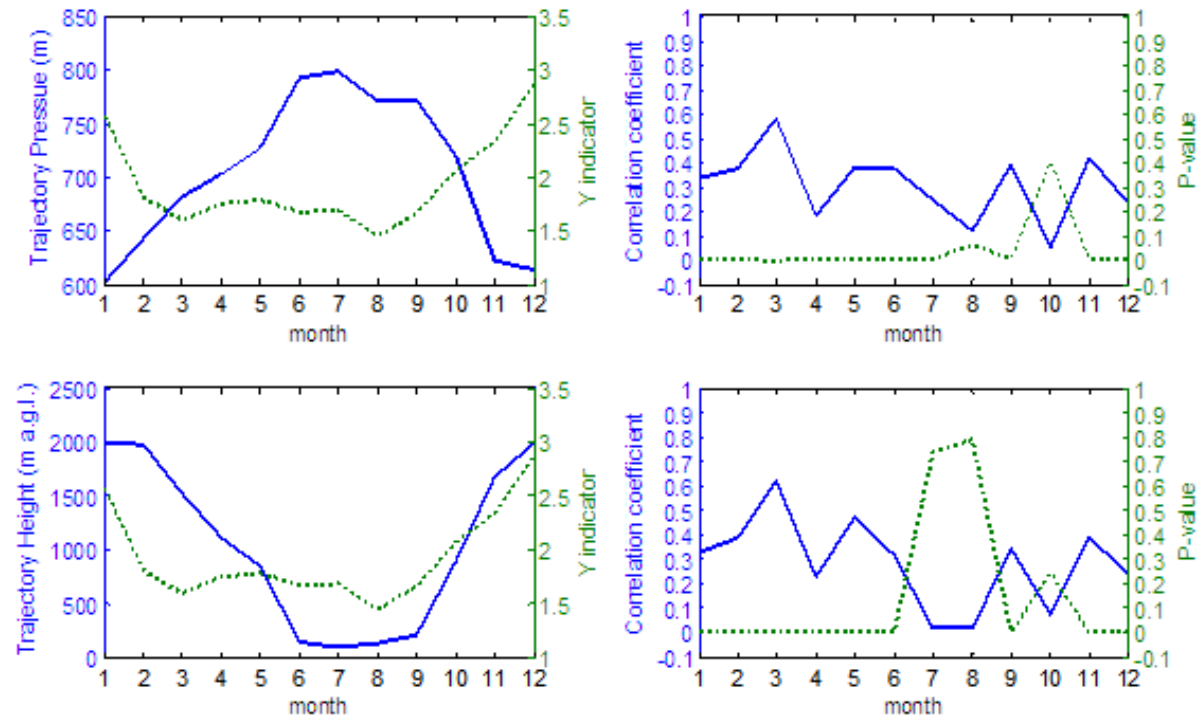

Figure 6. Correlation between trajectory pressure level or height and $Y$ indicator with significant levels $(P$ value $)$. The upper-left graph shows monthly trends of trajectory pressure and the $Y$ indicator, while the upper-right is the correlation between both. The lower-left graph shows monthly trends of the trajectory height and the $Y$ indicator, while the lower-right is the correlation between both. Note that correlation between trajectory pressure and $Y$ indicator is actually negative but is shown in absolute value.

Relationships between trajectory pressure (and height) and the $Y$ indicator are significant in January-June, September, November and December. The largest correlation coefficient (over 0.6) is found in March. In other months, the correlation remained around 0.2 to 0.4. Only in July, August and October is the correlation not significant, especially in terms of the relationship between trajectory height and $Y$ indicator. The differences in significance of correlations between the trajectories and the $Y$ indicator in the different months indicate the different contributions of the high-level air mass to surface air, resulting in the fluctuation of surface $\mathrm{O}_{3}, \mathrm{CO}$ and water vapor. The air mass advections from the upper atmosphere might contribute significantly to surface $\mathrm{O}_{3}$ in winter and spring. In terms of trajectory types, spring can be considered as the transition season, with the origins of the trajectories changing from the Tibetan Plateau with high trajectory heights to the southwest and south of Xianggelila with low trajectory heights. The low $Y$ indicator, trajectory height and the relationship between them in summer indicate that the factor mainly influencing surface $\mathrm{O}_{3}$ is not regional transport, but monsoon with abundant clouds and rain as discussed in Sect. 3.1. However, there may be exceptions for some shorter periods, as shown in the next section.

\subsection{A case of strong $\mathrm{O}_{3}$ downward transport}

In order to demonstrate that the $Y$ indicator can be used to reveal the events of $\mathrm{O}_{3}$ transport, we present here a case with a large $Y$ value from 6-7 July 2008. In this case, the $Y$ value reached 43.1 in the afternoon on 6 July 2008, and this is also the largest $Y$ value during the two years of observation. As shown in Fig. 7, surface $\mathrm{O}_{3}$ reached a peak value of $82.4 \mathrm{ppb}$ in the afternoon of 6 July 2008. At the same time, a sharp 


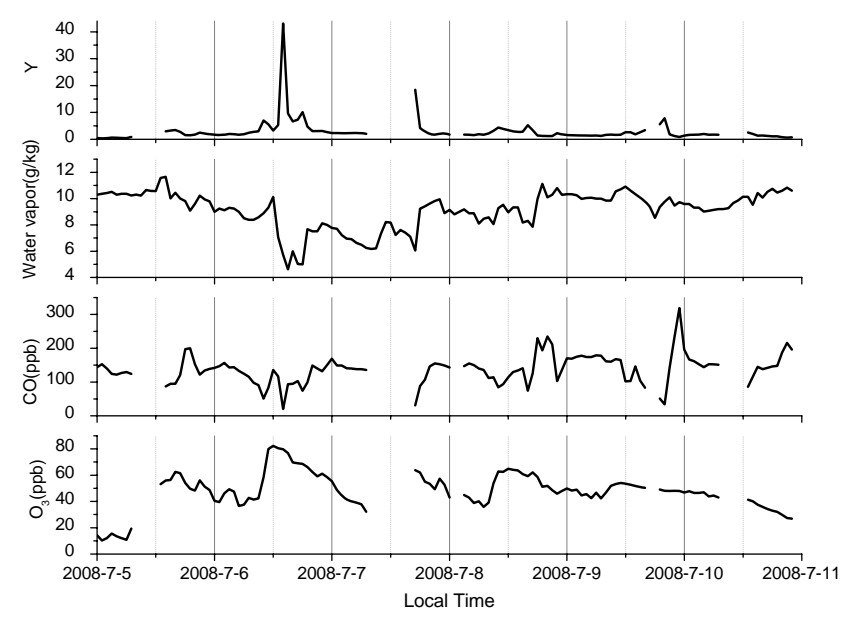

Figure 7. Time series of $Y$ value, water vapor, $\mathrm{CO}$ and $\mathrm{O}_{3}$ mixing ratios from 5 July to 11 July 2008.

decrease of water vapor was observed. Around the peak time of $\mathrm{O}_{3}$ at 13:00, $\mathrm{CO}$ also showed a low level close to the detection limit $(25 \mathrm{ppb})$ of the $\mathrm{CO}$ analyzer.

Figure 8 shows the seven-day backward trajectories initiated at 00:00 UTC each day during the period of 4-9 July 2008. On 4 July it is obvious that the air flows to Xianggelila originated from the southwest with slow speed and low height (near the surface). However, the airflow path largely changed from the southwest to the northwest on 5 July and kept the same features till 8 July especially with regard to the airflow in the higher layer (see trajectories for the endpoint height above $1200 \mathrm{~m}$ ). During this period, the air mass in the higher layer originated from relatively high elevations (from 6000 to $10000 \mathrm{~m}$ a.g.l.), which are indicative of the lower stratosphere, traveled very fast across the northern part of the Tibetan Plateau and reached the surface of Xianggelila. After 8 July the origin of the air mass changed back to the south/southwest, similar to that on 4 July. The airflow in the lower layer was also influenced by local air mass during 6-7 July. The co-effect of air mass of different origins in different air layers may shorten the lengthy period of high surface ozone level and often cause difficulty in identifying an event of $\mathrm{O}_{3}$ transport. The $Y$ indicator seems to be a good indicator, which can be further proved by the following evidence.

From 5 July to 8 July, a deep westerly trough developed to the east and northeast of Xianggelila (Fig. 9). This westerly trough began to impact Xianggelila on 5 July and extended southwesterly till 6 July, then retreated and diminished. The change of potential vorticity (PV) can be used to detect a strong stratospheric air intrusion into the troposphere across the tropopause. As shown in Fig. 9, a high PV tongue with a large gradient along the $2 \mathrm{PVU}$ (potential vorticity unit) line propagated southwesterly, which indicates a strong stratospheric air intrusion into the troposphere.

If $\mathrm{O}_{3}$ were strongly transported downward from the stratosphere to the troposphere, the total column ozone (TCO) would temporarily increase (Vaughan and Price, 1991). When the $\mathrm{O}_{3}$-rich air intruded into the troposphere, it changed the vertical distribution of $\mathrm{O}_{3}$ and caused a good correlation between the gradient of TCO (Fig. 10) and the gradient of PV (Fig. 9). In this case, the gradient of PV began to increase on 6 July when the TCO tongue appeared. The TCO value near Xianggelila (red star in Fig. 10) on 5 July was around $270 \mathrm{DU}$, and it began to increase on 6 July and reached $290 \mathrm{DU}$ on 8 and 9 July. This increase is attributed to the evolution of the high TCO tongue. Together with the downward trajectories in Fig. 8, this event shows that the deep westerly trough brought down the $\mathrm{O}_{3}$-rich air with less water vapor and $\mathrm{CO}$ into the troposphere and influenced the surface.

\subsection{Estimation of the frequency of $\mathrm{O}_{3}$ downward transport}

As discussed in Sect. 3.3, the $Y$ indicator can be used to indicate the effects of $\mathrm{O}_{3}$ downward transport. A transport event might last for dozens of hours at a high-lying surface site. So, if the $Y$ indicator stays at a relatively high level for several consecutive hours or days, there may be a high possibility of an intrusion event.

There are a total of $784 \mathrm{~h}$ with $Y$ higher than 3 , and the number of consecutive day with $Y$ higher than 3,4 and 5 are 200, 136 and 91, respectively, as shown in Table 3. The numbers of consecutive days with $Y$ higher than 8 are 15 in winter, 12 in fall and 4 in spring and summer, indicating that the $Y$-value-deduced occurrence of transport events varies largely from season to season. The downward transport occurred most frequently in winter, followed by fall and spring and was the least frequent in summer. The seasonal cycle of our $Y$ indicator (see Table 3 and Fig. 6) resembles that of the SI frequency at Mt. Cimone obtained by Cristofanelli et al. (2009) using a stratospheric intrusion index. Both indicators reveal that the downward transport of upper air is strongest in winter and weakest in summer. To analyze further the frequency of the downward transport, the relationship between the trajectory pressure level and $Y$ is analyzed. The number of hours with both $Y$ higher than a given value and a trajectory pressure level lower than a given level are calculated for each season and shown in Fig. 11. In summer, hours with both low trajectory pressure levels and high $Y$ values were rare, and this coincides with to the minimal $\mathrm{O}_{3}$ mixing ratio in summer. In the summer monsoon season, there were about $68.7 \%$ of days with precipitation at Xianggelila, which inhibits the accumulation of $\mathrm{O}_{3}$. The average trajectory height (only the maximal height of each trajectory is used) in summer was extremely low (134 m ending at $500 \mathrm{~m}$ a.g.l.), which limited the exchange of surface air with the upper free troposphere. In winter, the number of hours with both $Y$ higher than 2 and a trajectory pressure level lower than $500 \mathrm{hPa}$ is nearly $2400 \mathrm{~h}$. The pressures covered by the trajectories in winter were significantly lower, 

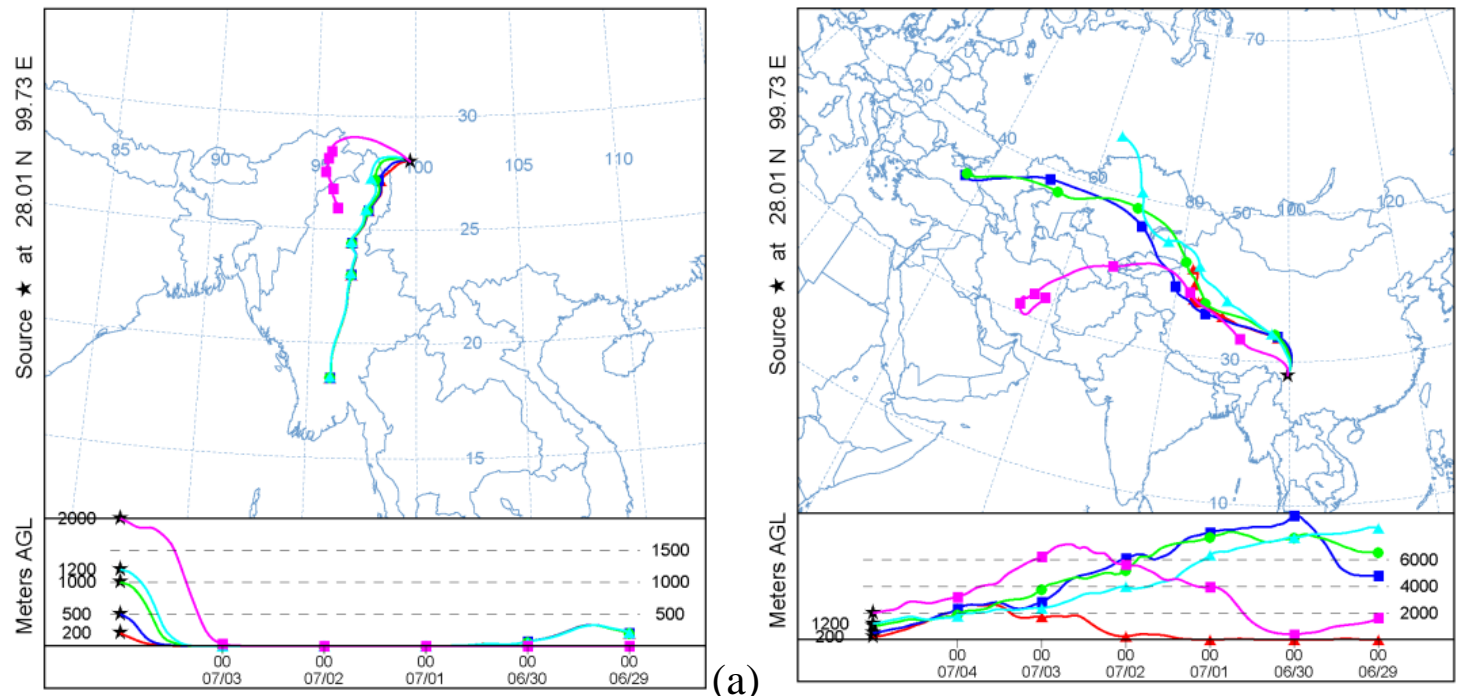

(b)
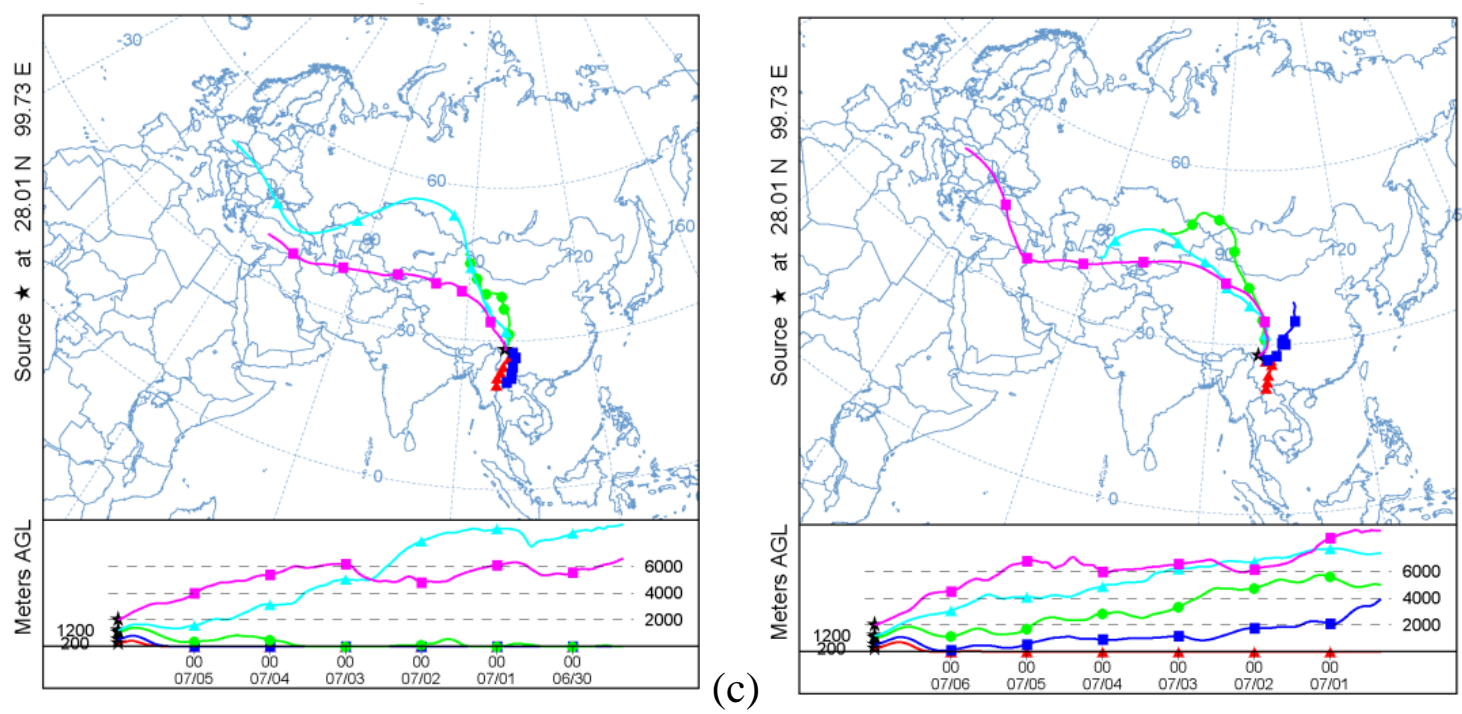

(d)

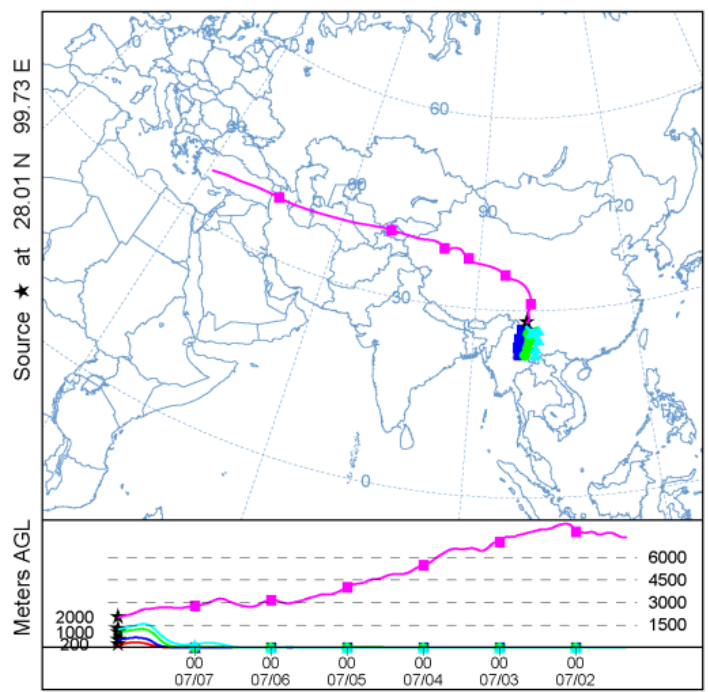

(c)

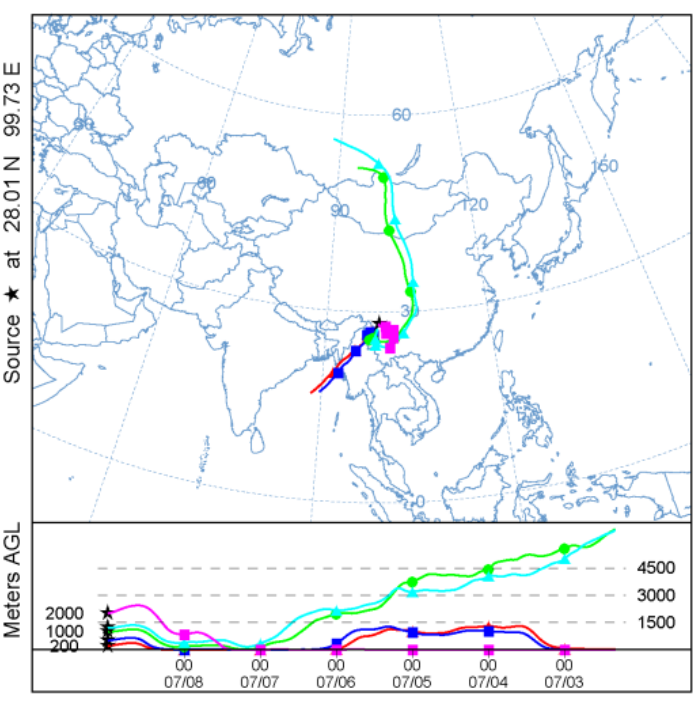

(f)

Figure 8. Seven-day backward trajectories arriving at different heights over Xianggelila from 4 July to 9 July 2008. Backward trajectories ending at 00:00 UTC on 4 July (a), 5 July (b), 6 July (c), 7 July (d), 8 July (e) and 9 July (f). 


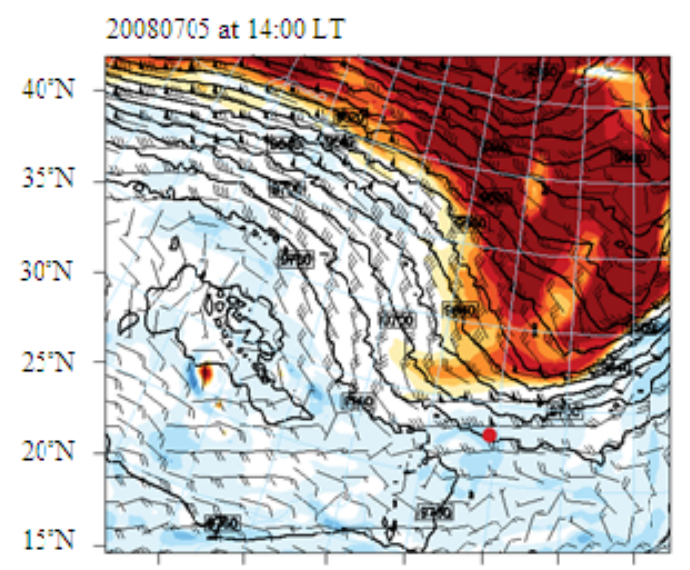

20080707 at $14: 00 \mathrm{LT}$

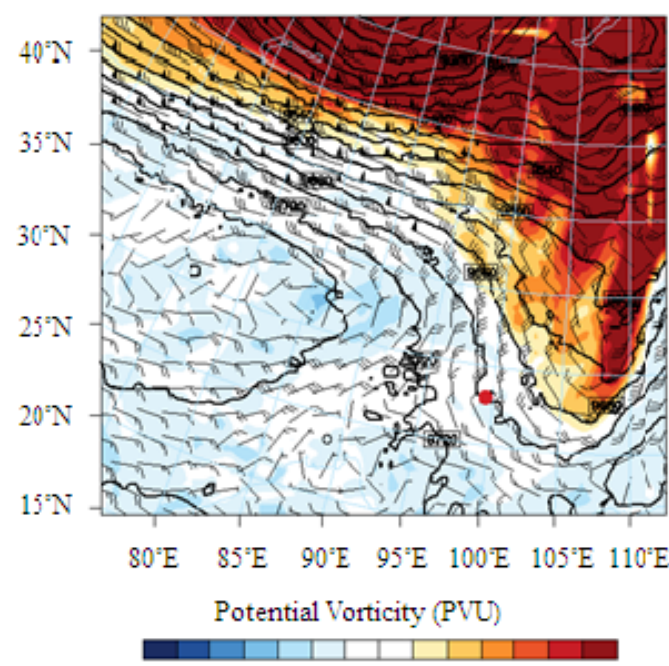

$-2 \cdot-1.5-1-.5 \quad 0 \quad 5 \quad 1 \quad 1.522 .5333 .54$

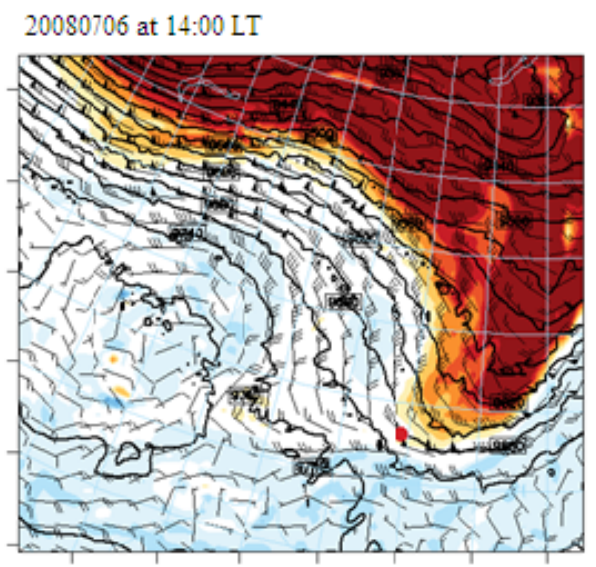

20070708 at 14:00 LT

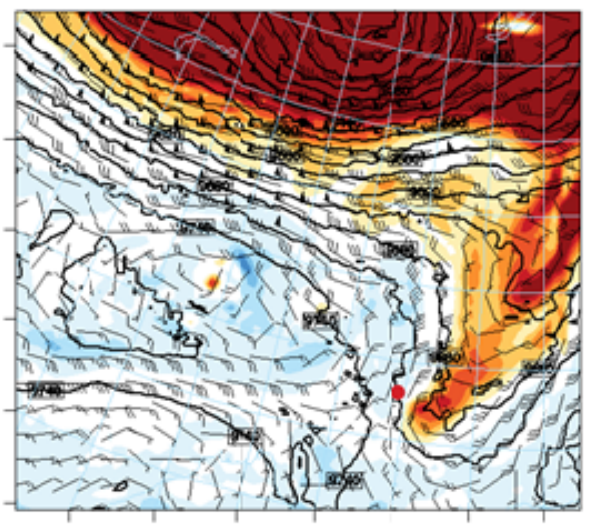

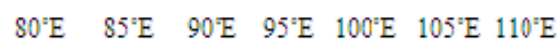

Potential Vorticity (PVU)

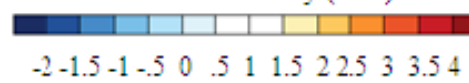

Figure 9. Geopotential height, horizontal wind vector at $300 \mathrm{hPa}$ and potential vorticity at $350 \mathrm{~K}$ from 5 July to 8 July 2008 . The filled red circle denotes the Xianggelila station.

indicating that relatively higher $\mathrm{O}_{3}$ from the upper atmosphere contributed to the surface $\mathrm{O}_{3}$ budget (Lefohn et al., 2001). The possibility of $\mathrm{O}_{3}$ transport events in fall was also high with a wide range of trajectories over $1000 \mathrm{~m}$ and $Y$ over 3. Together with Table 2, it is evident that the possible occurrences of $\mathrm{O}_{3}$-rich transport events prevailed in winter and then in fall or spring, but were rare in summer.

Corresponding to the different frequency of the transport events in the four seasons, the responses of surface $\mathrm{O}_{3}, \mathrm{CO}$ and water vapor for different trajectory pressure levels and the $Y$ indicator are examined. $\mathrm{O}_{3}, \mathrm{CO}$ and water vapor are averaged according to the results in Fig. 11. As shown in Fig. 12, the trends of surface $\mathrm{O}_{3}, \mathrm{CO}$ and water vapor correspond to the distribution patterns of the trajectory pressure level and $Y$ values in spring, fall and winter. The discriminable increase of $\mathrm{O}_{3}$ and the decrease of $\mathrm{CO}$ and water vapor can be found with the decrease of the trajectory pressure level and the increase of the $Y$ indicator, except in summer. Inter- estingly, the trend of $\mathrm{CO}$ in fall is similar to that in winter, but $\mathrm{O}_{3}$ does not show significant change with the variation of the trajectory pressure level or the $Y$ indicator. Because there is still monsoon influence in fall, even a higher frequency of transport cannot bring about a higher surface $\mathrm{O}_{3}$, possibly due to $\mathrm{O}_{3}$ destruction in continental stratus clouds (Wang and Sassen, 2000). This reflects that the dominant factor impacting $\mathrm{O}_{3}$ is monsoon in fall. The monsoon impact on decreasing $\mathrm{O}_{3}$ are also reported in India (Naja and Lal, 1996; Jain et al., 2005) and eastern China and the western Pacific region (e.g., He et al., 2008). From the correlation between the surface measurement and the trajectory height, as well as the $Y$ value, it is credible that the averaged surface $\mathrm{O}_{3}$ will increase when a transport event happens featuring low trajectory pressure level and a high $Y$ value, especially in winter. The increase of $\mathrm{O}_{3}$ caused by a deep transport event is estimated as $21.0 \%(+9.6 \mathrm{ppb})$ in winter; this is done by subtracting the winter average ozone level $(45.8 \mathrm{ppb})$ from the 

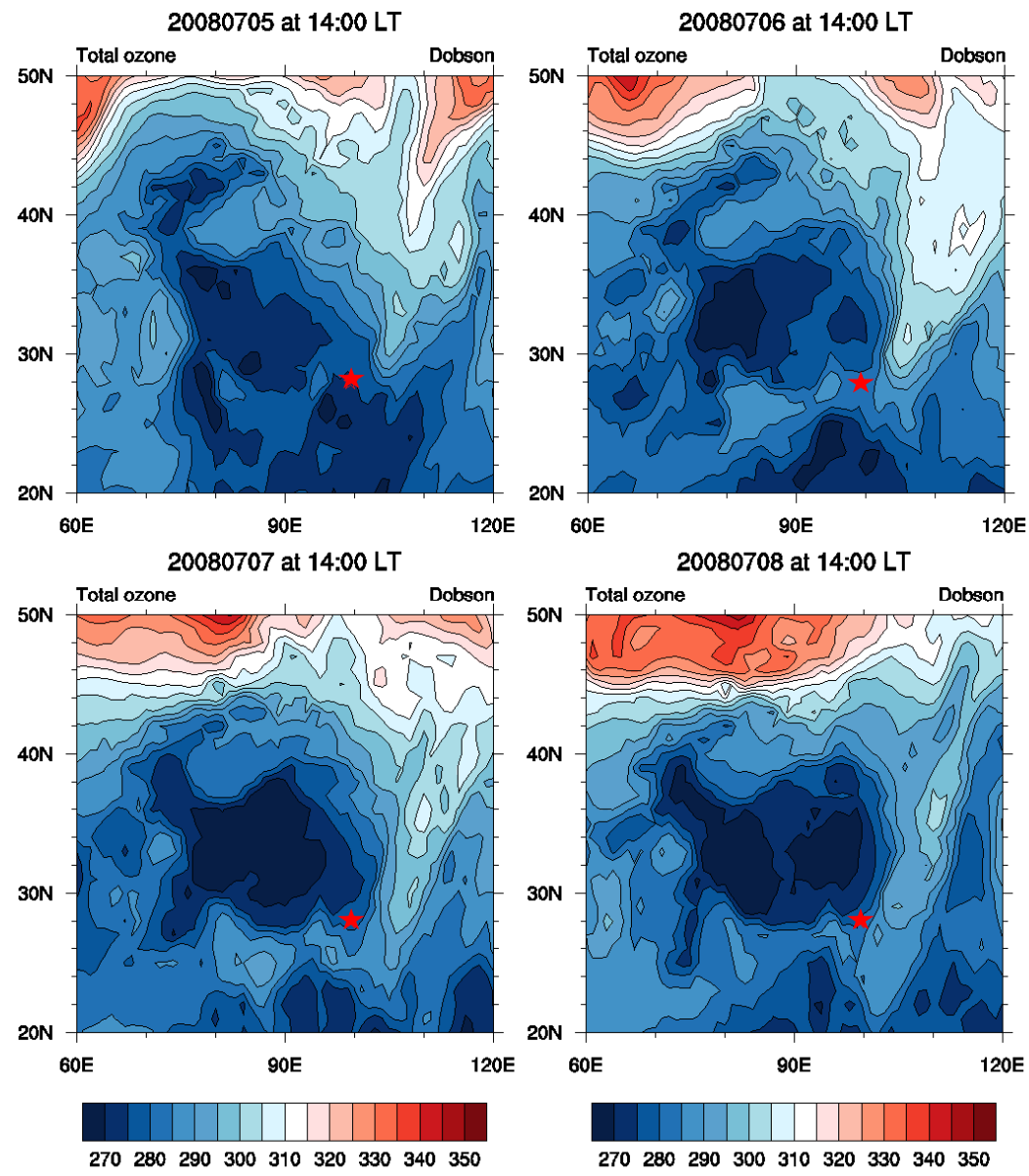

Figure 10. Total column $\mathrm{O}_{3}$ from 5 July to 8 July 2008. The red star denotes the Xianggelila station.

Table 3. Numbers of hours and consecutive days meeting the different $Y$ criteria.

\begin{tabular}{llrrrrrr}
\hline & $Y>3$ & $Y>4$ & $Y>5$ & $Y>6$ & $Y>7$ & $Y>8$ \\
\hline Numbers of hours & & 784 & 396 & 218 & 138 & 88 & 72 \\
\hline \multirow{2}{*}{ Numbers of } & Obs. period & 200 & 136 & 91 & 63 & 46 & 38 \\
consecutive days & Spring & 42 & 23 & 15 & 10 & 5 & 4 \\
& Summer & 32 & 14 & 11 & 9 & 5 & 4 \\
& Fall & 58 & 43 & 29 & 19 & 16 & 12 \\
& Winter & 65 & 53 & 32 & 21 & 17 & 15 \\
\hline
\end{tabular}

average $\mathrm{O}_{3}$ mixing ratio $(55.4 \mathrm{ppb})$ in the period in which the pressure level of both trajectories is lower than $400 \mathrm{hPa}$ and $Y$ is over 8. This is somewhat lower than the estimation of $\mathrm{O}_{3}$ increase $(27.1 \%,+13 \mathrm{ppb})$ due to stratospheric intrusions over NCO-P (Cristofanelli et al., 2010). In winter, the photochemical production of $\mathrm{O}_{3}$ is thought to be lowest. However, the winter level of the $\mathrm{O}_{3}$ average is $45.8 \pm 7.1 \mathrm{ppb}$ at the Xianggelila station, second only to that in spring. Therefore, most of the occurrences of $\mathrm{O}_{3}$ downward transport in winter may be an important reason for the higher winter level of surface $\mathrm{O}_{3}$ at Xianggelila.
Although the $Y$ indicator can be used to study the influence of transport from the upper $\mathrm{O}_{3}$-rich atmosphere and obtain qualitative or semi-quantitative results, there are still open questions such as which $Y$ indicator criteria may indicate a particular height for transport. Table 4 shows the monthly results of the $\mathrm{O}_{3}-\mathrm{CO}$ correlations, derived from measurements in Xianggelila at 10:00 to 18:00 (local time). The correlations are statistically significant from February to November. Relatively steep negative slopes are found in May, June, September, October and November and a flatter negative slope is found in December, suggesting that there 

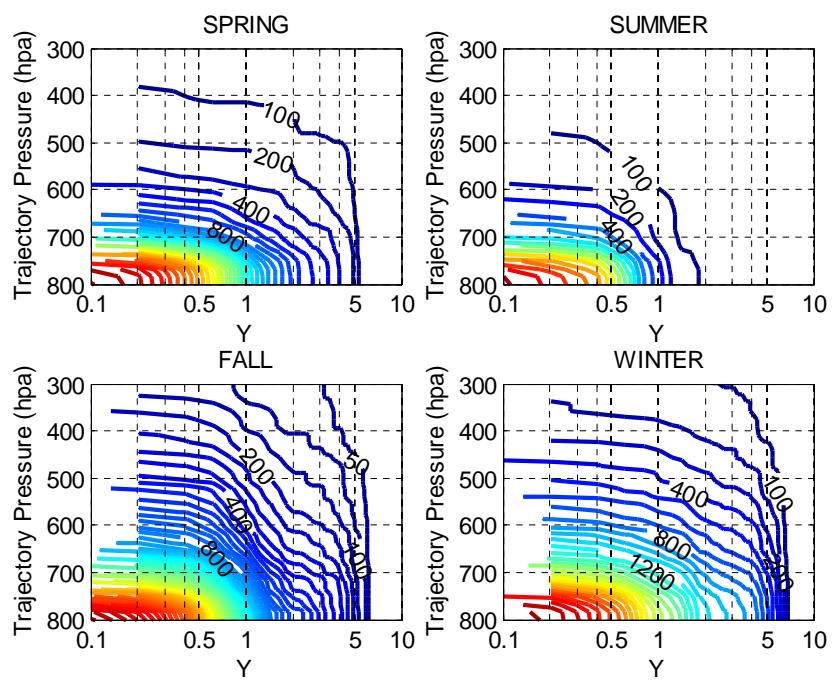

Figure 11. Hours with both trajectory pressure lower than and $Y$ value larger than given values in different seasons. Note that the $X$ axis is logarithmic.

Table 4. Monthly results of the $\mathrm{O}_{3}-\mathrm{CO}$ correlation derived from measurements in Xianggelila at 10:00 to 18:00 (local time). The slopes and intercepts of the regression lines were derived using the reduced-major-axis regression technique.

\begin{tabular}{lrrrrr}
\hline Month & Intercept & Slope & $R^{2}$ & $P$ & $N$ \\
\hline Jan & 33.5 & 0.109 & 0.0007 & 0.59 & 392 \\
Feb & 35.9 & 0.117 & 0.0494 & $<0.0001$ & 438 \\
Mar & 38.7 & 0.119 & 0.1950 & $<0.0001$ & 521 \\
Apr & 39.7 & 0.136 & 0.1160 & $<0.0001$ & 519 \\
May & 83.4 & -0.192 & 0.0531 & $<0.0001$ & 509 \\
Jun & 85.2 & -0.344 & 0.0861 & $<0.0001$ & 516 \\
Jul & -14.0 & 0.347 & 0.0540 & $<0.0001$ & 497 \\
Aug & -3.1 & 0.233 & 0.0411 & $<0.0001$ & 515 \\
Sep & 67.5 & -0.251 & 0.0547 & $<0.0001$ & 461 \\
Oct & 65.2 & -0.285 & 0.1080 & $<0.0001$ & 499 \\
Nov & 58.4 & -0.183 & 0.0693 & $<0.0001$ & 420 \\
Dec & 50.7 & -0.094 & 0.0551 & 0.02 & 300 \\
\hline
\end{tabular}

are clear influences from the upper troposphere and lower stratospheric air masses in these months. Significant positive $\mathrm{O}_{3}-\mathrm{CO}$ correlations with steeper slopes are found in July, August, February, March and April, which indicates that the influences of photochemical production of $\mathrm{O}_{3}$ is probably more important in these months.

\section{Conclusions}

A two-year measurement of surface $\mathrm{O}_{3}$ and $\mathrm{CO}$ was made from December 2007 to November 2009 at Xianggelila in southwest China. The maximal $\mathrm{O}_{3}$ and $\mathrm{CO}$ mixing ratios were observed in spring, followed by those observed in winter and fall, and the minima were in summer. According to the analysis of backward trajectories, Xianggelila was influenced largely by the high and fast airflows from the southern or northern Tibet Plateau in winter, fall and spring. In summer, trajectories to Xianggelila were mainly from the southern and eastern regions, and their moving heights were very low and under the influence of the Asian monsoon from the end of May to the end of September. As a result, minimal $\mathrm{O}_{3}$ was found in summer due to frequent precipitation and cloudiness being most frequent in this season. The $\mathrm{CO}$ level in summer remained at a relatively high level because of the air transport from the southern and eastern regions with intense anthropogenic $\mathrm{CO}$ emissions. The $\mathrm{CO}$ level was low in winter because the air masses originated partly from the relatively clean Tibetan Plateau.

A downward transport indicator $(Y)$, which combined the measured data of the chemical tracers of $\mathrm{O}_{3}, \mathrm{CO}$ and water vapor is proposed as an indicator of the fluctuation of $\mathrm{O}_{3}$ and sources from the $\mathrm{O}_{3}$-rich free troposphere. By using monthly normalized values in the calculation of $Y$, seasonal influences in the concentrations of tracers are minimized, so that the results from different seasons can be compared. A strong transport event is revealed by the largest $Y$ indicator (43.1) during two years' observation and discussed using trajectory and weather analysis. The event was associated with a strong westerly trough and resulted in enhanced surface $\mathrm{O}_{3}$. Together with the trajectory pressure level, the analysis of $Y$ reveals that the most frequent transport occurred in winter, followed by that in fall, spring and summer. This is consistent with the seasonality of the subtropical jet (Koch et al., 2006) and STE in the Northern Hemisphere, especially regarding results reported for the Tibetan Plateau (e.g., Sprenger et al., 2003; Chen et al., 2011; Škerlak et al., 2014), and it resembles that of deep stratospheric intrusions over central Europe (Trickl et al., 2010, 2011). It also shows a similar seasonal cycle to the SI frequency obtained at Mt. Cimone by Cristofanelli et al. (2009) using an SI index, the general idea and structure of which are similar with the $Y$ indicator. The winter maximum of the frequency of downward transport corresponds well to the relatively high $\mathrm{O}_{3}$, relatively low $\mathrm{CO}$ and water vapor levels at Xianggelila. Therefore, downward transport of air masses contributes significantly to the winter level of surface $\mathrm{O}_{3}$ at Xianggelila. The increase of winter $\mathrm{O}_{3}$ is estimated to be $21.0 \%$ ( $\left.+9.6 \mathrm{ppb}\right)$ due to the impact of deep $\mathrm{O}_{3}$ transport events. 

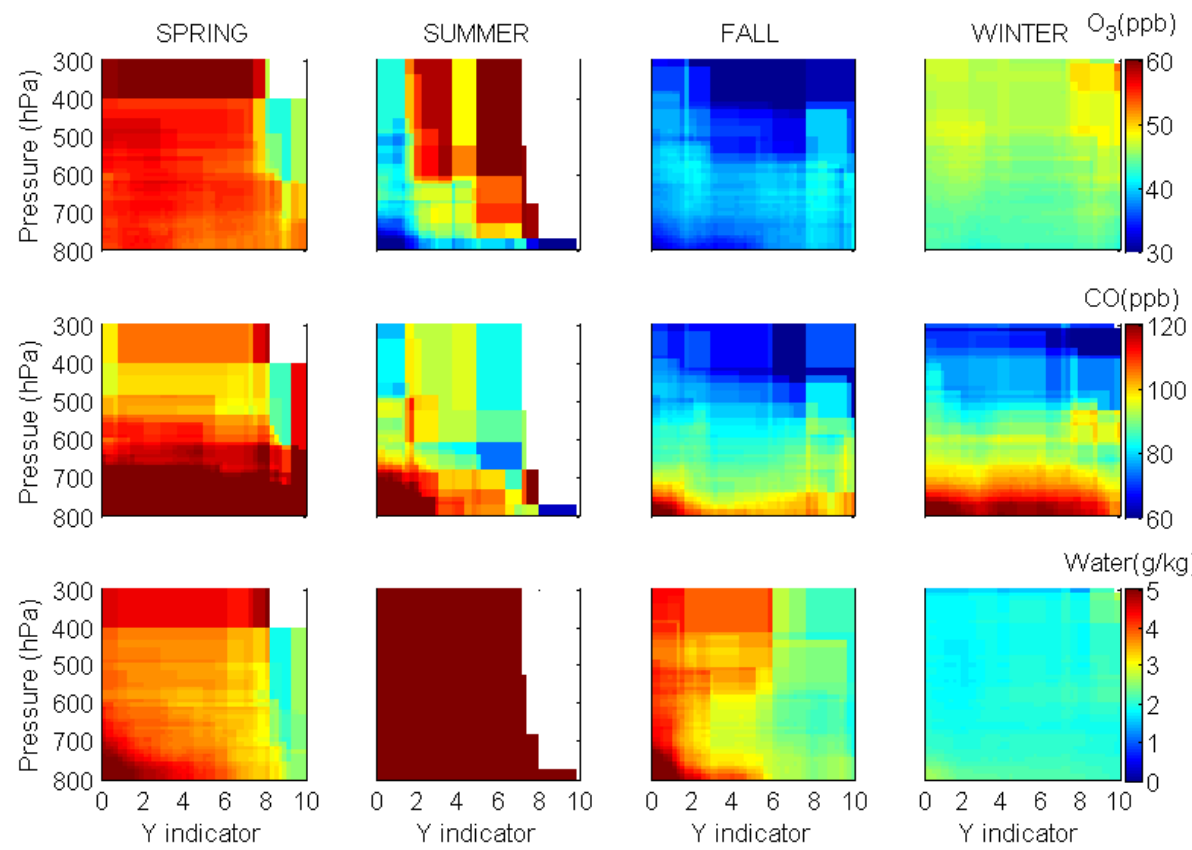

Figure 12. Distributions of the values of $\mathrm{O}_{3}, \mathrm{CO}$ and water vapor above specific trajectory pressure levels and the values of the $Y$ indicator. The $Y$-axis denotes trajectory pressure (hPa) and the $X$ axis denotes the $Y$ indicator. The unit of the color bar of $\mathrm{O}_{3}$ and $\mathrm{CO}$ is ppb; that of water vapor is $\mathrm{g} \mathrm{kg}^{-1}$.

Acknowledgements. We thank the staff in Diqing Meteorological Bureau for their help during the measurements. This work is supported by Natural Science Foundation of China (21177157, 40830102) and the China Special Fund for Meteorological Research in the Public Interest (GYHY201106023) and Basic Research Fund of CAMS(2011Z003).

Edited by: T. Wang

\section{References}

Bonasoni, P., Evangelisti, F., Bonafe, U., Ravegnani, F., Calzolari, F., Stohl, A., Tositti, L., Tubertini, O., and Colombo, T.: Stratospheric ozone intrusion episodes recorded at Mt. Cimone during the VOTALP project: case studies, Atmos. Environ., 34, 13551365, 2000.

Bukin, O. A., An, N. S., Pavlov, A. N., Stolyarchuk, S. Y., and Shmirko, K. A.: Effect that Jet Streams Have on the Vertical Ozone Distribution and Characteristics of Tropopause Inversion Layer in the Far East Region, Izvestiya, Atmospheric and Oceanic Physics, 47, 610-618, 2011.

Chameides, W. and Walker, J. C. G.: A photochemical theory of tropospheric ozone, J. Geophys. Res., 78, 8751-8760, 1973.

Chen, X. L., Ma, Y. M., Kelder, H., Su, Z., and Yang, K.: On the behaviour of the tropopause folding events over the Tibetan Plateau, Atmos. Chem. Phys., 11, 5113-5122, doi:10.5194/acp11-5113-2011, 2011.

Chen, X., Anel, J. A., Su, Z., de la Torre, L., Kelder, H., van Peet, J., and Ma, Y.: The deep atmospheric boundary layer and its significance to the stratosphere and troposphere ex- change over the Tibetan Plateau, PLOS ONE, 8, e56909, doi:10.1371/journal.pone.0056909, 2013.

Cheng, S. Y., Huang, G. H., Chakma, A., Hao, R. X., Liu L., and Zhang, X. H.: Estimation of atmospheric mixing heights using data from airport meteorological stations, J. Environ. Sci. Heal. A, 36, 521-532, 2001.

Cooper, O., Moody, J., Parrish, D., Trainer, M., Holloway, J., Hübler, G., Fehsenfeld, F., and Stohl, A.: Trace gas composition of midlatitude cyclones over the western North Atlantic Ocean: A seasonal comparison of $\mathrm{O}_{3}$ and CO, J. Geophys. Res., 107, 4057, doi:10.1029/2001JD000902, 2002.

Cristofanelli, P., Calzolari, F., Bonafè, U., Duchi, R., Marinoni, A., Roccato, F., Tositti, L., and Bonasoni, P.: Stratospheric intrusion index $\left(\mathrm{SI}^{2}\right)$ from baseline measurement data, Theor. Appl. Climatol., 97, 317-325, 2009.

Cristofanelli, P., Bracci, A., Sprenger, M., Marinoni, A., Bonafè, U., Calzolari, F., Duchi, R., Laj, P., Pichon, J. M., Roccato, F., Venzac, H., Vuillermoz, E., and Bonasoni, P.: Tropospheric ozone variations at the Nepal Climate ObservatoryPyramid (Himalayas, $5079 \mathrm{~m}$ a.s.1.) and influence of deep stratospheric intrusion events, Atmos. Chem. Phys., 10, 6537-6549, doi:10.5194/acp-10-6537-2010, 2010.

Crutzen, P. J.: Photochemical reactions initiated by and influencing ozone in unpolluted tropospheric air, Tellus, 26, 47-57, 1974.

Crutzen, P. J., Lawrence, M. G., and Pöschl, U.: On the background photochemistry of tropospheric ozone, Tellus B, 51, 123-146, 1999.

Danielsen, E. F.: Stratospheric-tropospheric exchange based on radioactivity, ozone and potential vorticity, J. Atmos. Sci., 25, 502518, 1968. 
Davies, T. and Schuepbach, E.: Episodes of high ozone concentrations at the earth's surface resulting from transport down from the upper troposphere/lower stratosphere: a review and case studies, Atmos. Environ., 28, 53-68, 1994.

Ding, A. and Wang, T.: Influence of stratosphere-to-troposphere exchange on the seasonal cycle of surface ozone at Mount Waliguan in western China, Geophys. Res. Lett., 33, L03803, doi:10.1029/2005GL024760, 2006.

Draxler, R. and Rolph, G.: HYSPLIT (HYbrid Single-Particle Lagrangian Integrated Trajectory) model access via NOAA ARL READY website (http://www.arl.noaa.gov/ready/hysplit4.html, last access: 30 April 2014). NOAA Air Resources Laboratory, Silver Spring, MD, 2003.

Fishman, J., Solomon, S., and Crutzen, P. J.: Observational and theoretical evidence in support of a significant in-situ photochemical source of tropospheric ozone, Tellus, 31, 432-446, 1979.

Gettelman, A., Kinnison, D. E., Dunkerton, T. J., and Brasseur, G. P.: Impact of monsoon circulations on the upper troposphere and lower stratosphere, J. Geophys. Res., 109, D22101, doi:10.1029/2004JD004878, 2004.

Gidel, L. T. and Shapiro, M.: General circulation model estimates of the net vertical flux of ozone in the lower stratosphere and the implications for the tropospheric ozone budget, J. Geophys. Res., 85, 4049-4058, 1980.

He, Y. J., Uno, I., Wang, Z. F., Pochanart, P., Li, J., and Akimoto, H.: Significant impact of the East Asia monsoon on ozone seasonal behavior in the boundary layer of Eastern China and the west Pacific region, Atmos. Chem. Phys., 8, 7543-7555, doi:10.5194/acp-8-7543-2008, 2008.

Hough, A. M. and Derwent, R. G.: Changes in the global concentration of tropospheric ozone due to human activities, Nature, 344, 645-648, 1990.

Jacob, D. J.: Heterogeneous chemistry and tropospheric ozone, Atmos. Environ., 34, 2131-2159, 2000.

Jain, S., Arya, B., Kumar, A., Ghude, S. D., and Kulkarni, P.: Observational study of surface ozone at New Delhi, India, Int. J. Remote Sens., 26, 3515-3524, 2005.

Junge, C. E.: Global ozone budget and exchange between stratosphere and troposphere, Tellus, 14, 363-377, 1962.

Klausen, J., Zellweger, C., Buchmann, B., and Hofer, P.: Uncertainty and bias of surface ozone measurements at selected Global Atmosphere Watch sites, J. Geophys. Res., 108, 4622, doi:10.1029/2003JD003710, 2003.

Koch, P., Wernli, H., and Davies, H. C.: An Event-based Jet-stream Climatology and Typology, Int. J. Climatol., 26, 283-301, 2006.

Krupa, S. V. and Manning, W. J.: Atmospheric ozone: formation and effects on vegetation, Environ. Pollut., 50, 101-137, 1988.

Langford, A. O.: Stratosphere-troposphere exchange at the subtropical jet, contribution to the tropospheric ozone budget at midlatitudes, Geophys. Res. Lett, 26, 2449-2452, 1999.

Langford, A. O., OLeary, T. J., Masters, C. D., Aikin, K. C., and Proffitt, M. H.: Modulation of middle and upper tropospheric ozone at Northern midlatitudes by the El Niño/Southern Oscillation, Geophys. Res. Lett., 25, 2667-2670, 1998.

Langford, A., Aikin, K., Eubank, C., and Williams, E.: Stratospheric contribution to high surface ozone in Colorado during springtime, Geophys. Res. Lett., 36, L12801, doi:10.1029/2009GL038367, 2009.
Lefohn, A. S., Oltmans, S. J., Dann, T., and Singh, H. B.: Presentday variability of background ozone in the lower troposphere, J. Geophys. Res., 106, 9945-9958, 2001.

Liang, M. C., Tang, J., Chan, C. Y., Zheng, X., and Yung, Y. L.: Signature of stratospheric air at the Tibetan Plateau, Geophys. Res. Lett., 35, L20816, doi:10.1029/2008GL035246, 2008.

Logan, J., Staehelin, J., Megretskaia, I., Cammas, J. P., Thouret, V., Claude, H., De Backer, H., Steinbacher, M., Scheel, H. E., and Stübi, R.: Changes in ozone over Europe: Analysis of ozone measurements from sondes, regular aircraft (MOZAIC) and alpine surface sites, J. Geophys. Res., 117, D09301, doi:10.1029/2011JD016952, 2012.

Ma, J., Zhou, X., and Hauglustaine, D.: Summertime tropospheric ozone over China simulated with a regional chemical transport model 2. Source contributions and budget, J. Geophys. Res., 107, 4612, doi:10.1029/2001JD001355, 2002.

Ma, J., Zheng, X. D., and Xu, X. D.: Comment on "Why does surface ozone peak in summertime at Wa Liguan?" by Bin Zhu et al., Geophys. Res. Lett., 32, 01805, doi:10.1029/2004GL021683, 2005.

Marenco, A., Thouret, V., Nédélec, P., Smit, H., Helten, M., Kley, D., Karcher, F., Simon, P., Law, K., and Pyle, J.: Measurement of ozone and water vapor by Airbus in-service aircraft: The MOZAIC airborne program, an overview, J. Geophys. Res., 103, 25631-25642, 1998.

Monks, P. S.: A review of the observations and origins of the spring ozone maximum, Atmos. Environ., 34, 3545-3561, 2000.

Moore, G. and Semple, J. L.: A Tibetan Taylor Cap and a halo of stratospheric ozone over the Himalaya, Geophys. Res. Lett., 32, L21810, doi:10.1029/2005GL024186, 2005.

Naja, M. and Lal, S.: Changes in surface ozone amount and its diurnal and seasonal patterns, from 1954-55 to 1991-93, measured at Ahmedabad (23 N), India, Geophys. Res. Lett., 23, 81-84, 1996.

Neuman, J., Trainer, M., Aikin, K., Angevine, W., Brioude, J., Brown, S., de Gouw, J., Dube, W., Flynn, J., and Graus, M.: Observations of ozone transport from the free troposphere to the Los Angeles basin, J. Geophys. Res., 117, D00V09, doi:10.1029/2011JD016919, 2012.

Oltmans, S., Lefohn, A., Shadwick, D., Harris, J., Scheel, H., Galbally, I., Tarasick, D., Johnson, B., Brunke, E.-G., and Claude, H.: Recent tropospheric ozone changes - A pattern dominated by slow or no growth, Atmos. Environ., 67, 331-351, 2013.

Ordóñez, C., Brunner, D., Staehelin, J., Hadjinicolaou, P., Pyle, J., Jonas, M., Wernli, H., and Prévôt, A.: Strong influence of lowermost stratospheric ozone on lower tropospheric background ozone changes over Europe, Geophys. Res. Lett., 34, L07805, doi:10.1029/2006GL029113, 2007.

Parrish, D. D., Law, K. S., Staehelin, J., Derwent, R., Cooper, O. R., Tanimoto, H., Volz-Thomas, A., Gilge, S., Scheel, H.-E., Steinbacher, M., and Chan, E.: Long-term changes in lower tropospheric baseline ozone concentrations at northern mid-latitudes, Atmos. Chem. Phys., 12, 11485-11504, doi:10.5194/acp-1211485-2012, 2012.

Randel, W. J., Seidel, D. J., and Pan, L. L.: Observational characteristics of double tropopauses, J. Geophys. Res., 112, D07309, doi:10.1029/2006JD007904, 2007.

Rolph, G.: Real-time Environmental Applications and Display sYstem (READY) Website (http://ready.arl.noaa.gov, last access: 17 
October 2013). NOAA Air Resources Laboratory, Silver Spring, MD, USA, 2010.

Skamarock, W. C., Klemp, J. B., Dudhia, J., Gill, D. O., Barker, D. M., Wang, W., and Powers, J. G.: A description of the Advanced Research WRF Version 2, DTIC Document, 2005.

Škerlak, B., Sprenger, M., and Wernli, H.: A global climatology of stratosphere-troposphere exchange using the ERA-Interim data set from 1979 to 2011, Atmos. Chem. Phys., 14, 913-937, doi:10.5194/acp-14-913-2014, 2014.

Sprenger, M. and Wernli, H.: A northern hemispheric climatology of cross-tropopause exchange for the ERA15 time period (19791993), J. Geophys. Res., 108, 8521, doi:10.1029/2002JD002636, 2003.

Sprenger, M., Maspoli, M. C., and Wernli, H.: Tropopause folds and cross-tropopause exchange: A global investigation based upon ECMWF analyses for the time period March 2000 to February 2001, J. Geophys. Res., 108, 8518, doi:10.1029/2002JD002587, 2003.

Staehelin, J., Harris, N., Appenzeller, C., and Eberhard, J.: Ozone trends: A review, Rev. Geophys., 39, 231-290, 2001.

Stohl, A. and Trickl, T.: A textbook example of long-range transport - Simultaneous observation of ozone maxima of stratospheric and North American origin in the free troposphere over Europe, J. Geophys. Res., 104, 445-462, 1999.

Stohl, A., Spichtinger-Rakowsky, N., Bonasoni, P., Feldmann, H., Memmesheimer, M., Scheel, H., Trickl, T., Hübener, S., Ringer, W., and Mandl, M.: The influence of stratospheric intrusions on alpine ozone concentrations, Atmos. Environ., 34, 1323-1354, 2000

Tang, J., Wen, Y., Xu, X., Zheng, X., Guo, S., and Zhao, Y.: China global atmosphere watch baseline observatory and its measurement program, CAMS Annual Report 1994-1995, China Meteorology Press, Beijing, 56-65, 1995.

Tilmes, S., Pan, L. L., Hoor, P., Atlas, E., Avery, M. A., Campos, T., Christensen, L. E., Diskin, G. S., Gao, R.-S., Herman, R. L., Hintsa, E. J., Loewenstein, M., Lopez, J., Paige, M. E., Pittman, J. V., Podolske, J. R., Proffitt, M. R., Sachse, G. W., Schiller, C., Schlager, H., Smith, J., Spelten, N., Webster, C., Weinheimer, A., and Zondlo, M. A.: An aircraft-based upper troposphere lower stratosphere $\mathrm{O}_{3}, \mathrm{CO}$, and $\mathrm{H}_{2} \mathrm{O}$ climatology for the Northern Hemisphere, J. Geophys. Res., 115, D14303, doi:10.1029/2009JD012731, 2010.
Trickl, T., Feldmann, H., Kanter, H.-J., Scheel, H.-E., Sprenger, M., Stohl, A., and Wernli, H.: Forecasted deep stratospheric intrusions over Central Europe: case studies and climatologies, Atmos. Chem. Phys., 10, 499-524, doi:10.5194/acp-10-499-2010, 2010.

Trickl, T., Bärtsch-Ritter, N., Eisele, H., Furger, M., Mücke, R., Sprenger, M., and Stohl, A.: High-ozone layers in the middle and upper troposphere above Central Europe: potential import from the stratosphere along the subtropical jet stream, Atmos. Chem. Phys., 11, 9343-9366, doi:10.5194/acp-11-9343-2011, 2011.

Vaughan, G. and Price, J.: On the relation between total ozone and meteorology, Q. J. Roy. Meteor. Soc., 117, 1281-1298, 1991.

Vingarzan, R.: A review of surface ozone background levels and trends, Atmos. Environ., 38, 3431-3442, 2004.

Wang, T., Wong, H., Tang, J., Ding, A., Wu, W., and Zhang, $\mathrm{X}$.: On the origin of surface ozone and reactive nitrogen observed at a remote mountain site in the northeastern QinghaiTibetan Plateau, western China, J. Geophys. Res., 111, D08303, doi:10.1029/2005JD006527, 2006.

Wang, Z. and Sassen, K.: Ozone destruction in continental stratus clouds: An aircraft case study, J. Appl. Meteorol., 39, 875-886, 2000.

$\mathrm{Xu}, \mathrm{X}$., Tang, J., and Lin, W.: The trend and variability of surface ozone at the global GAW station Mt. WALIGUAN, China, in: "Second Tropospheric Ozone Workshop Tropospheric Ozone Changes: Observations, state of understanding and model performances", WMO/GAW report, WMO, Geneva, 49-55, 2011.

Xue, L. K., Wang, T., Zhang, J. M., Zhang, X. C., Deliger, Poon, C. N., Ding, A. J., Zhou, X. H., Wu, W. S., Tang, J., Zhang, Q. Z., and Wang, W. X.: Source of surface ozone and reactive nitrogen speciation at Mount Waliguan in western China: New insights from the 2006 summer study, J. Geophys. Res., 116, D07306, doi:10.1029/2010JD014735, 2011.

Zheng, X., Wan, G., Tang, J., Zhang, X., Yang, W., Lee, H., and Wang, C.: ${ }^{7} \mathrm{Be}$ and ${ }^{210} \mathrm{~Pb}$ radioactivity and implications on sources of surface ozone at Mt. Waliguan, Chinese Sci. Bull., 50, 167-171, 2005.

Zheng, X., Shen, C., Wan, G., Liu, K., Tang, J., and Xu, X.: ${ }^{10} \mathrm{Be} /{ }^{7} \mathrm{Be}$ implies the contribution of stratosphere -troposphere transport to the winter-spring surface $\mathrm{O}_{3}$ variation observed on the Tibetan Plateau, Chinese Sci. Bull., 56, 84-88, 2011. 